\title{
Sustainable development indicators for wastewater systems - researchers and indicator users in a co-operative case study
}

\author{
Ulrika Palme*, Margareta Lundin, Anne-Marie Tillman, \\ Sverker Molander \\ Department of Environmental Systems Analysis, Chalmers University of Technology, \\ SE 41296 Göteborg, Sweden
}

Received 8 December 2003; accepted 18 June 2004

\begin{abstract}
This paper presents a study where sustainable development indicators (SDIs) for sludge handling and wastewater treatment systems were constructed in co-operation with a large Swedish water company. Results from a life cycle assessment, a risk assessment, an economic assessment and an uncertainty assessment were used as inputs for ranking technical options of sludge handling by use of multi-criteria analysis (MCA). The MCA included assessment of the different technical options, valuation of different, and often conflicting, aspects of sustainability and weighting of various criteria. On basis of the preferences expressed in the MCA, a number of SDIs and, when possible, targets for sustainable development, were formulated. The resulting SDIs reflected economic, environmental, technical and social aspects of sustainable development of sludge handling systems. Where possible, the coverage of the indicators was extended to the entire wastewater system.
\end{abstract}

(C) 2004 Elsevier B.V. All rights reserved.

Keywords: Sustainable development; Indicators; Life cycle assessment; Multi-criteria analysis; Sludge handling; Wastewater systems; LCA

* Corresponding author. Tel.: +46 31772 8607; fax: +46 317722172.

E-mail address: ulrika.palme@esa.chalmers.se (U. Palme). 


\section{Introduction}

The production and delivery of drinking water and the conduction and treatment of wastewater are vital functions in any society; hence securing them for current and future generations is an important part of sustainable development. This has also been recognised in many of the initiatives to measure different aspects of sustainability and select appropriate sustainable development indicators (SDIs) that were launched following the U.N. conference on Environment and Development in Rio de Janeiro in 1992. Initially, a majority of the SDIs proposed were intended for use at the international, national, regional or other administrative or geographical levels (see, e.g. OECD, 1998; UNCSD, 1996; Verbruggen and Kuik, 1991), and included suggestions on indicators such as withdrawal of freshwater (OECD), sewage connection rates (OECD) and releases of nitrogen and phosphorus (UNCSD) (for review see Lundin, 1999). In the latter half of the 1990s the role and responsibility of companies in the implementation of sustainable development attracted increasing attention, leading to a new set of initiatives, now to develop SDIs for use at the company level. The use of SDIs within companies in general is described by e.g. Bennett and James (1999), Fiksel et al. (1999), Olsthoorn et al. (2000), Schaltegger and Burritt (2000), Veleva and Ellenbecker (2001) and Veleva et al. (2001). SDI projects applying specifically to the water industry are reviewed by e.g. Balkema et al. (2002) and Foxon et al. (2002). There are among these projects, within the water sector or elsewhere, few examples of successful implementation of SDIs, i.e. SDIs made operational. The reasons for this are most likely manifold, but it is increasingly understood that sustainability issues at company level call for extended involvement of employees if management towards increased sustainability is to be successful (Schelin et al., 2003) and this is often ignored (Azzone et al., 1996; Noci, 2000).

This paper reports on a co-operative case study aiming at the construction of operational SDIs for a water company. The study involved the indicator users (company staff and one member of the board) and researchers, in order to provide indicators that meet the needs of the company to indicate its contribution to a sustainable development. The study was focused on wastewater and sludge handling systems and included the conduct of LCA, risk and uncertainty assessment, economic assessment and multi-criteria analysis of a number of sludge handling options.

\section{The case study at Stockholm Water Company - background, outline and assessments}

The Stockholm Water Company (SWC) is the largest water company in Sweden and operates the municipal drinking water and wastewater system in Stockholm and Huddinge. Its activities extend to the production and distribution of drinking water for over one million people and the handling and treatment of wastewater for 900,000 people. The company has a long tradition of environmental reporting and has the goal of contributing to the long-term sustainable development of society (SWC, 2002). Over the years 2000-2002, a case study was performed in co-operation between researchers at Chalmers University of Technology and representatives of SWC with the aim of identifying SDIs. Researchers 


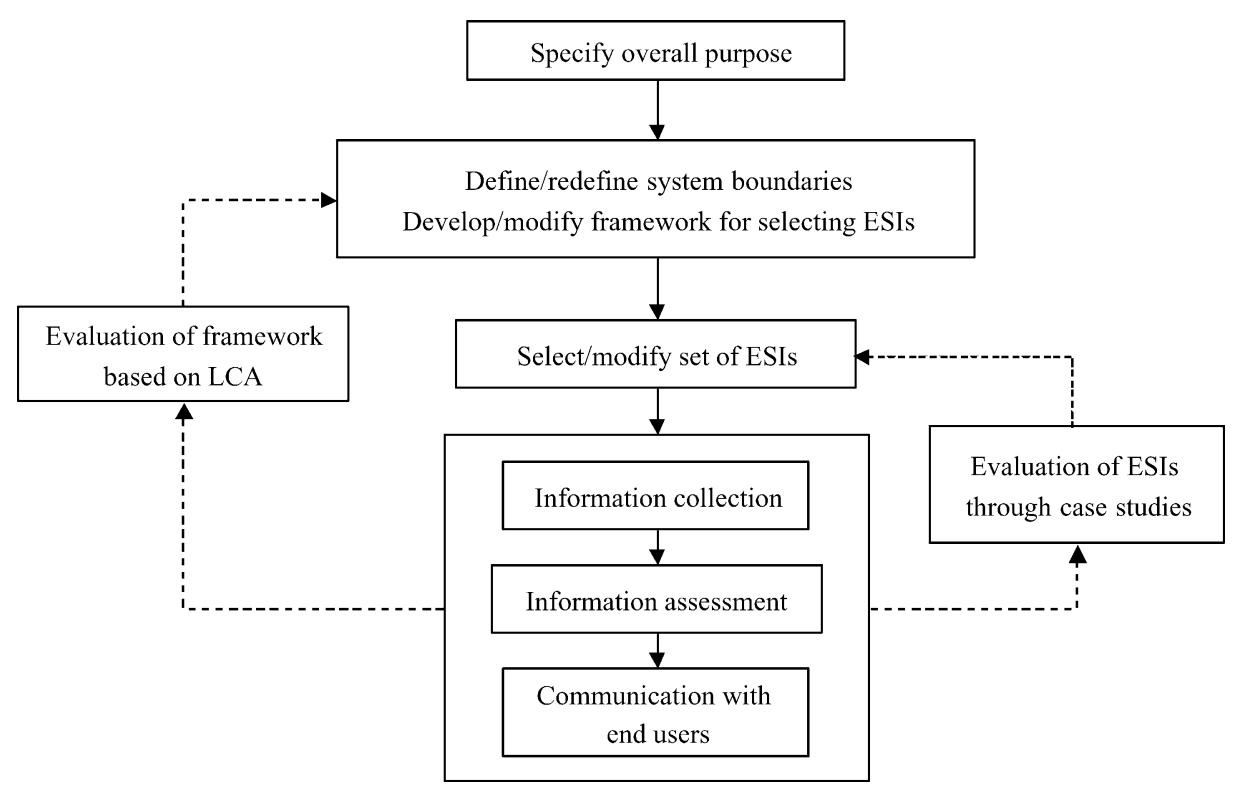

Fig. 1. Iterative procedure for constructing environmental sustainability indicators (ESIs) to assess the sustainability of urban water systems (Lundin and Morrison, 2002).

at the Department of Environmental Systems Analysis (ESA) in the university initiated the project and were primarily responsible for coordinating the project, collecting much of the information, preparing background documents and synthesising the results. A working group was formed including employees representing technical and economic departments at SWC and one member of the board. An iterative procedure for construction of indicators suggested by Lundin and Morrison (2002), Fig. 1, was established as a point of departure, though modified by adding economic and social aspects to the environmental aspects.

In the initial meetings with SWC the intended use of SDIs was discussed; it was decided to aim at identifying SDIs with special applicability to the choice of technical options for sludge handling, and with a general bearing on the development of the entire wastewater system. Thus, the case study had to incorporate two different SDI objectives: support in choice among technology options, and guidance of long-term development towards sustainability, as well as two different system levels: the sludge handling system and the entire wastewater system.

Discussions on the meaning of sustainable development were oriented towards the information required in order to assess the different technical options for sludge handling from different aspects. From a sustainability perspective, the management of sewage sludge is strategic. It contains valuable resources such as phosphorus and soil-conditioning substances, but also harmful substances such as heavy metals, persistent organic compounds and pathogens that can be transmitted to plants, livestock and humans (e.g. Spinosa and Veslind, 2001). 
In 1994, an agreement was made between the Swedish Environmental Protection Agency (NVV), the Federation of Swedish Farmers (LRF) and Swedish Water (at that time the Swedish Water and Wastewater Association, VAV) to work for the increased use of sewage sludge in agriculture. The agreement included limit and guideline values for heavy metals and a number of organic substances (NVV et al., 1995). However, in 1999 the LRF advised their members not to spread sewage sludge on agricultural land as traces of brominated flame retardants had been found in sewage sludge; since then, agricultural use of sludge has become less and less feasible. Furthermore, from 2005, landfill of organic material will be prohibited by Swedish law. The debate on how to handle sludge is ongoing.

\subsection{Outline}

Starting from the iterative procedure suggested by Lundin and Morrison (2002), Fig. 1, a procedure for the construction of SDIs in the case study was worked out in co-operation with SWC, Fig. 2. A set of assessments: LCA, economic assessment, risk assessment (mainly qualitative) and uncertainty assessment (purely qualitative), were used to evaluate a number of options for sludge handling. In addition, a literature study on production and availability of phosphorus was performed as a complement to the LCA.

Four sludge handling options were chosen for assessment in the study:

1. Spreading of pasteurised sludge on agricultural land;

2. Co-incineration with household waste;

3. Separate incineration followed by phosphorus recovery by the Bio-Con process;

4. Fractionation by acid hydrolysis for recovery of phosphorus with the Cambi-KREPRO process.

Agricultural use implies that plant-available nitrogen, phosphorus, other nutrients and organic material contained in sludge, are recycled and thereby form potential substitutes for conventional fertilisers in agricultural production. Agricultural use, however, is made difficult by the presence of various contaminants in sewage sludge, as pointed out in the preceding section.

A possible future option is co-incineration of sludge with household waste. The energy content in the sludge can then be recovered to generate district heating and electricity, but the nutrients in the sludge are lost since ashes from the co-incineration process are too contaminated for nutrient recovery.

Recovery of nutrients, especially phosphorus, is attracting increasing attention, which has led to the development of alternative sludge handling technologies. Bio-Con and CambiKREPRO are two such technologies, both developed recently. Both technologies enable recovery of phosphorus, heat and compounds such as precipitation chemicals, as well as the separation of heavy metals for removal. The processes involved require substantial amounts of chemicals such as sulphuric acid and sodium hydroxide. However, the function, environmental impact and cost of these new technologies at full-scale need to be further evaluated (Balmér et al., 2002; Hultman et al., 2001).

The results from the assessments were compiled and presented to the members of the SWC working group and subsequently used as input to the ranking of sludge handling 


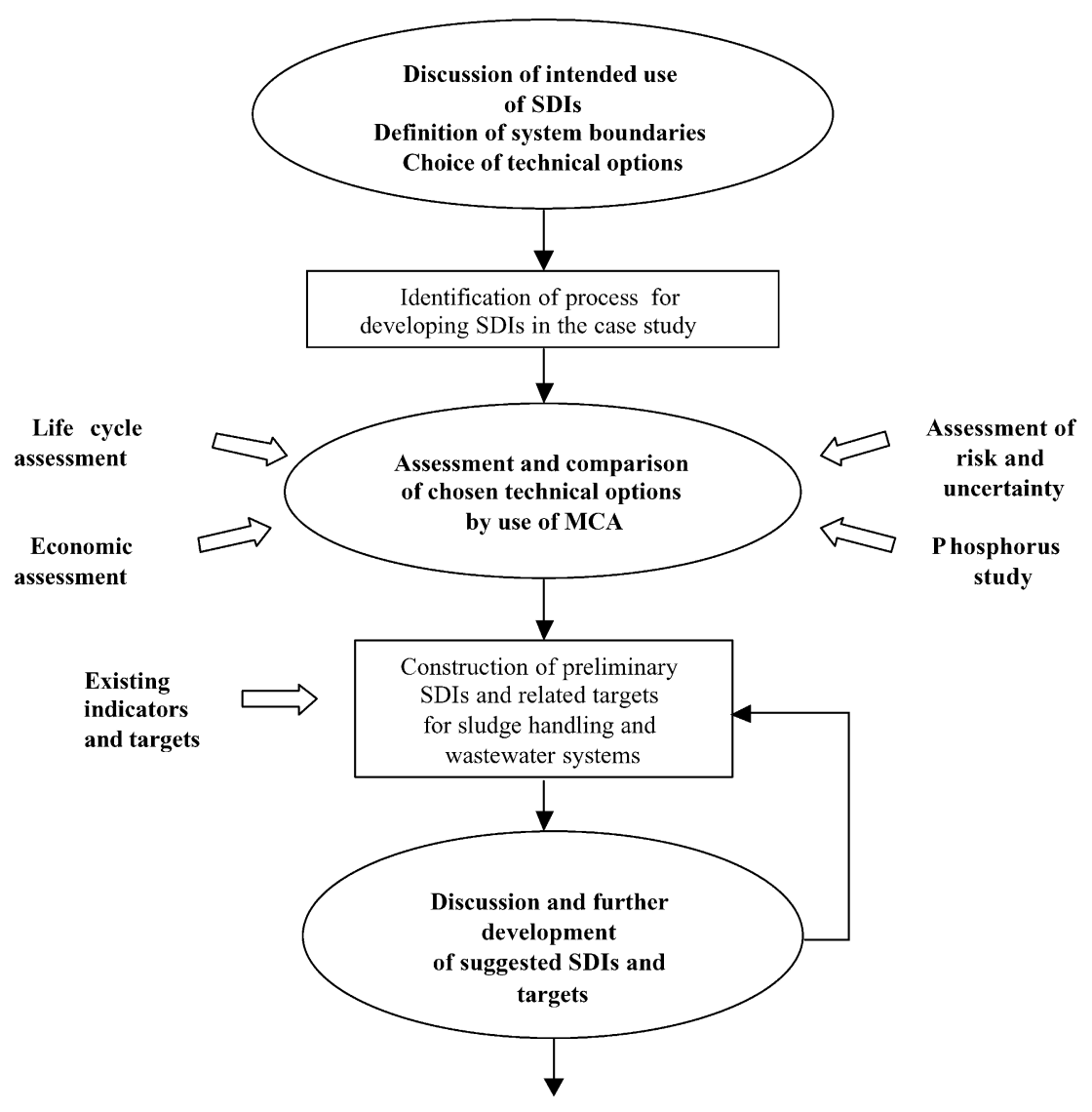

Final set of SDIs and targets

Fig. 2. Outline of procedure in the Stockholm Water Company case study. Activities within oval shapes were carried out by researchers and the SWC working group together.

options with regard to long-term demands on the system and its function as part of a sustainable society by use of multi-criteria analysis (MCA). On the basis of the preferences expressed in the MCA, which included the assessment of the various technical options, the valuation of different and often conflicting aspects of sustainability and the weighting of different criteria, SDIs and, where possible, targets for sustainable development, were formulated. The choice of technical option as such was not considered of prime importance for the construction of SDIs, but rather the arguments brought forward for making that choicearguments that were also reflected in the weighting of different criteria. The resulting SDIs covered economic, environmental, technical and social aspects of sustainable development of sludge handling systems. Where possible, the coverage of the indicators was extended to the entire wastewater system. 


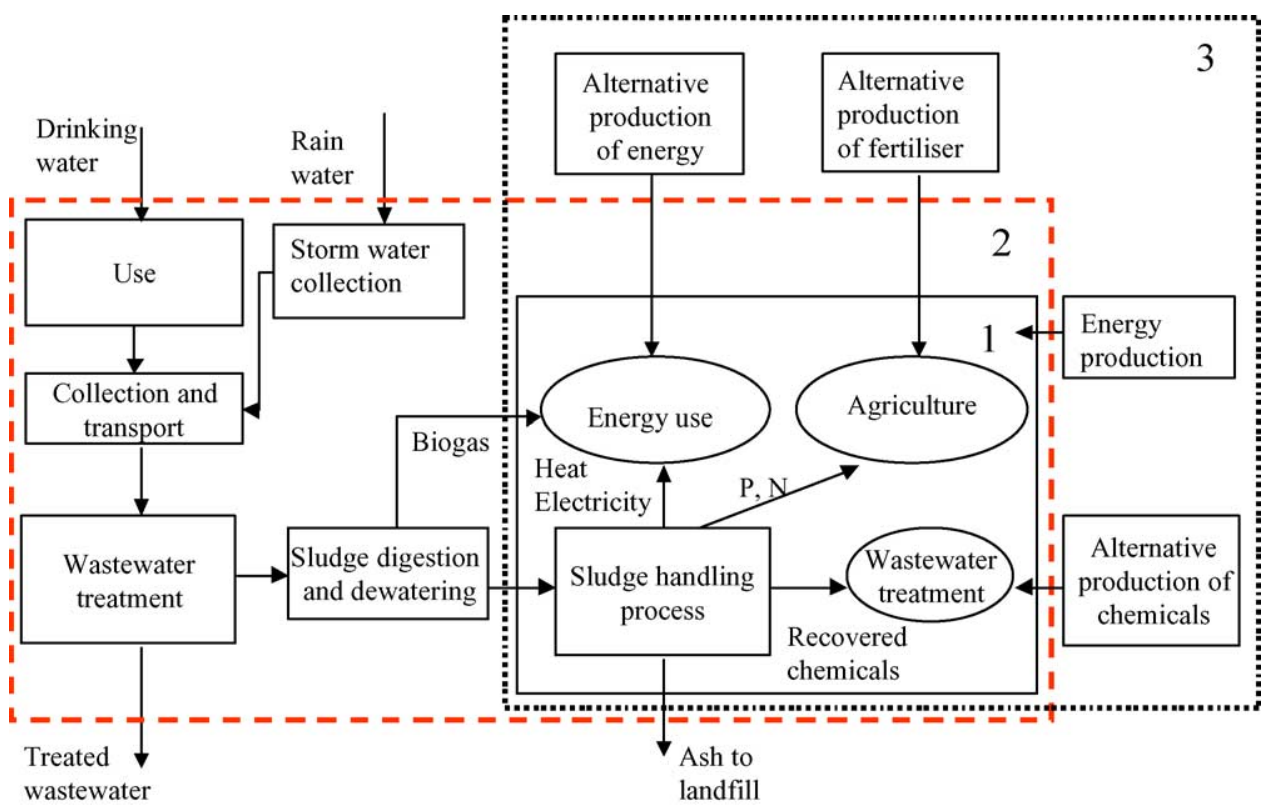

Fig. 3. Overview of system boundaries for the construction of SDIs and for the LCA. The arrows indicate the flows of energy and materials through the system. Set 1: SDIs for sludge handling; set 2: SDIs for the wastewater system; set 3: LCA for sludge handling (all transports are included but not shown in the figure). Processes in oval shapes were not modelled in the LCA.

\subsection{Assessments}

\subsubsection{Life cycle assessment (LCA)}

Results from an LCA study of the four sludge handling options in question, carried out for the Rya wastewater treatment plant in Göteborg, formed input to the environmental assessment (Lundin et al., 2004; Pettersson, 2001). Data on the energy system, distance to farmland, etc. were hence based on Göteborg conditions, but these are similar for Stockholm. Sludge transport, incineration, spreading, phosphorus processing, and production of chemicals and electricity were included in the study (Fig. 3, set 3 system boundaries). In those options where products are recovered (phosphorus and nitrogen, chemicals, electricity and heat), these were assumed to replace alternative production of the commodity. Only impacts imposed by the operation of the sludge handling were modelled - not the impacts imposed from the construction of the facilities. Organic pollutants and pathogens were not considered, nor was leakage of metals and other environmental effects that originate from disposal of ashes to landfills.

Life cycle impact assessment (LCIA) (ISO 14042, 2000) was performed using three different steps: classification of substances into environmental impact categories followed by characterisation; normalisation of inventory results by means of relating specific emissions and resources to the total amount emitted or used in Sweden per person per year, according to a method developed by Kärrman and Jönsson, 2001; and weighting of different envi- 
Table 1

Data from the economic and the environmental assessments of one metric tonne of dry matter sewage sludge

\begin{tabular}{|c|c|c|c|c|}
\hline Criterion & Agricultural use & Co-incineration & Bio-Con & Cambi-Krepro \\
\hline \multicolumn{5}{|l|}{ Economy } \\
\hline Total cost, $\mathrm{SEK}^{\mathrm{a}}$ & 680 & 2440 & 1380 & 1790 \\
\hline \multicolumn{5}{|l|}{ Resource use } \\
\hline Phosphorus, kg & -18 & & -21 & -15 \\
\hline Sulphur, kg & & & 73 & 91 \\
\hline Electricity, kWh & -40 & -330 & 200 & 330 \\
\hline Oil, kg & 53 & -21 & -33 & -16 \\
\hline Fossil gas, kg & 5 & -80 & -65 & -36 \\
\hline \multicolumn{5}{|l|}{ Emissions to air } \\
\hline $\mathrm{CO}_{2}, \mathrm{~kg}$ & 50 & -310 & -340 & -150 \\
\hline $\mathrm{NO}_{x}, \mathrm{~g}$ & 2020 & 960 & 1100 & 640 \\
\hline $\mathrm{SO}_{x}, \mathrm{~g}$ & -520 & -350 & -310 & -210 \\
\hline $\mathrm{Hg}, \mathrm{g}$ & & 0.1 & 0.5 & 0.1 \\
\hline Dioxins & & Non-detectable & $\mathrm{Ca} 1 \mathrm{mg}$ & Non-detectable \\
\hline \multicolumn{5}{|l|}{ Emissions to ground } \\
\hline Heavy metals & To arable land & To landfill & $\begin{array}{l}\text { To landfill and } \\
\text { disposal of hazardous } \\
\text { waste }\end{array}$ & $\begin{array}{l}\text { To landfill and } \\
\text { disposal of hazardous } \\
\text { waste }\end{array}$ \\
\hline Organic compounds & To arable land & & & \\
\hline
\end{tabular}

Environmental data is reported according to common LCA practice, i.e. positive values refer to consumption of resources and emissions of pollutants; negative values refer to avoided burdens, i.e. saved resource consumption and avoided emissions.

a Swedish kronor.

ronmental impacts against each other by use of two weighting methods, ET Long and EPS (Baumann and Rydberg, 1994; Steen, 1999).

Generally, the LCA identified energy use, phosphorus depletion and emissions of heavy metals as the three most important environmental aspects of sludge handling (Pettersson, 2001). In all options except co-incineration, phosphorus is recovered in amounts of similar magnitude (see Table 1, showing data from the economic and environmental assessments). In the Bio-Con and Cambi-KREPRO processes this is achieved at the expense of a significant use of sulphur: 3.4 and $6 \mathrm{~kg}$, respectively, per $\mathrm{kg}$ of phosphorus recovered.

Energy recovery is of great importance through its immediate connection to a reduced depletion of fossil resources and reduced atmospheric emissions of carbon dioxide, nitrogen oxides and sulphur oxides. These potential reductions favour the three options with incineration (co-incineration, Bio-Con and Cambi-KREPRO), where energy recovery replaces alternative energy sources. Incineration of sludge, however, leads to small atmospheric emissions of substances such as mercury and dioxins. In addition, the three incineration options generate ashes that need to be landfilled or handled as hazardous waste.

Spreading sludge on agricultural land was the least preferable option with regard to most environmental aspects, as it is energy-demanding and transfers all potential contaminants of sewage sludge, such as heavy metals and organic compounds, to agricultural land. The use 
of fossil fuels and related air emissions are connected to the pasteurisation, transportation and spreading of sludge. Also of importance, but not included in Table 1, were the ammonia emissions from the spreading of sludge. These emissions depend largely on how and when sludge is spread.

\subsubsection{Risk assessment}

As a complement to the LCA, a general model was developed for risk assessment of hazardous compounds in sludge spread on agricultural land. The model included hazard identification, exposure assessment, effects assessment with focus on human health, and simple risk classification (van Leeuwen, 1995). As a specific example, national data on flows and background levels of cadmium (Enskog Broman, 2000; NVV, 2000) were entered in the model.

The risk assessment confirmed that in a general context the issue of hazardous compounds in sludge is extremely complex, including several chemical and biological processes of which many have not yet been thoroughly investigated. In the cadmium example, it was shown that cadmium in sewage sludge amounts to $2.2 \%$ of the total annual anthropogenic flow in Sweden. The actual effects on human health of cadmium in sludge used on agricultural land depend on a number of factors such as soil characteristics and choice of crops.

\subsubsection{Phosphorus}

Phosphorus as a resource is neglected in most LCIA weighting methods. A complementary literature review was therefore performed on the availability, national flows and environmental impact of the production of phosphorus from different sources. The global availability turned out to have the largest influence on the selection of SDIs at SWC. About $80 \%$ of world phosphate production is derived from sedimentary deposits. These are often comparatively high in grade, but also more contaminated with potentially hazardous elements such as cadmium, arsenic and radionuclides than the igneous deposits. Some of the deposits in Morocco, where reserves are estimated to account for about 50\% of all global reserves, contain as much as $40 \mathrm{mg}$ cadmium per kg rock. Removing the contaminants requires high energy inputs and generates hazardous waste, which is estimated to increase the cost of conventional fertilisers by 2-10\% (Steen, 1998). In the industrialised world, agricultural soil is generally high in phosphorus as a result of a deliberate fertiliser regime. In other parts of the world there will be increasing demand for phosphorus as a fertilizer (Smil, 2000).

\subsubsection{Economic assessment}

Results for the economic assessment of the four sludge handling options were obtained from a study performed for the Rya wastewater treatment plant in Göteborg in parallel with the LCA serving as input to the environmental assessment (Zetterlund, 2001; Lundin et al., 2004). The costs were analysed from a municipal perspective, i.e. only the financial costs for the municipality were analysed. In general, the system boundaries were the same for the economic assessment as for the LCA, but the economic assessment included both capital and operational costs. (In the LCA only the impacts from the operation were assessed.) 
The results of the economic assessment expressed as the total cost is shown in the first data row of Table 1. Spreading on arable land had the lowest cost, and co-incineration the highest (Zetterlund, 2001). In the case of spreading sludge on agricultural land, the total net cost is dominated by the transport from the wastewater treatment plant to farmland, which accounts for almost $50 \%$, followed by the capital cost of the new pasteurisation process, which corresponds to about $22 \%$ of total net cost.

Of the total net cost for co-incineration, $65 \%$ is accounted for by investment in new capacity for waste incineration. The total cost for this option is remarkably high, especially in comparison with the Bio-Con and Cambi-KREPRO options. For these two relatively new technologies there remain, however, a great number of uncertainties. According to the assessment, the capital cost for Bio-Con accounts for approximately 58\% of net cost. The operational costs of this option are more than halved when revenues from sale of produced chemicals, district heating and electricity are taken into account. Compared to this amount, the revenues of co-incineration are low. The distribution of costs and revenues for the Cambi-KREPRO option show a similar pattern to that of Bio-Con.

\subsubsection{Uncertainty assessment}

Uncertainties were assessed using a qualitative approach, including literature review and discussions with the working group at SWC, leading to a definition of the important categories of uncertainties influencing sludge handling now and in the future. These were:

- Future sludge quality as a result of the use and handling of chemicals in society.

- Future general attitude towards the use in agriculture of sludge or other products originating from wastewater.

- Economy, reliability and working environment of the Bio-Con, Cambi-KREPRO and other new technologies.

- Future development of the urban water system and the systems connected to it (energy, transport and agriculture).

\section{Multi-criteria analysis}

To proceed from the assessments of the four sludge handling options to a set of SDIs, an MCA was performed; the aim here was to generate a structured discussion on sustainable development and thereby facilitate the expression of SWC's preferences. The chosen procedure was a participatory one of mathematical simplicity and high transparency, following largely the multi-criteria evaluation process described in Stirling and Mayer (1999).

Preparatory to the MCA meeting, a number of criteria for the evaluation of the sludge handling options were selected by the researchers after consulting the SWC working group. Economy, expressed as the total cost from a municipal perspective, was selected as one criterion. As environmental criteria, the parameters found to be dominant in the LCIA were selected. Phosphorus as a natural resource was added because the result of the complementary study performed on phosphorus confirmed its importance. In addition, acceptance, reliability of service, working conditions and hygiene were added as criteria in spite of not being assessed prior to the MCA. The criteria finally used in the MCA were economy, 
resources, energy, emissions to air, emissions to ground, acceptance, reliability of service, working conditions and hygiene. Key results from the economic and environmental assessments were compiled into an interim report that was distributed to all participants before the MCA meeting.

The MCA meeting, led by 2 researchers and attended by 10 SWC representatives (seven full-time employees, two temporary employees and one member of the board) was recorded for full documentation. The meeting opened with a presentation of the assessment results of the four technical options, followed by a long discussion around the various criteria and the data presented under each. The four criteria of acceptance, reliability of service, working conditions and hygiene were not accompanied by any data at the beginning of the MCA meeting, but qualitative data were added during that meeting, primarily by SWC (see data in regular font and italics, respectively, in Table 2).

After the initial discussion, the participants from SWC worked individually to score the options with respect to each criterion, using an agreed scale of 1-5. This step in the procedure meant judging the performance of each technical option with regard to each specific criterion, with a 3 for "acceptable performance", 5 for "excellent performance", etc., without considering the importance of the criterion as such in relation to other criteria. Mean scores based on the scoring performed by eight persons (the full-time employees and the board member) are shown in Table 2.

Next step in the MCA procedure was to assess the importance of the selected criteria by weighting (assigning large weights to important criteria and smaller weights to the less important). This was performed by setting a weight of 100 for economy and judging the other criteria in relation to this. The criteria were weighted with regard to the specific situation, not per se. For example, hygiene was given a low weight not because hygiene is not considered important, but because in this context (handling of pasteurised sludge and incineration of sludge) it was not considered a problem. The weighting procedure was first attempted as a group task, but due to lengthy discussions this had to be interrupted and replaced by individual weighting. The resulting mean weights are shown in Table 2, as is the total sum assigned to each option, with and without weights.

Several comments were made on the MCA procedure during and after the meeting. The participants considered it unfair to have four criteria relating to environment and only one relating to economy. Different ways of grouping the criteria for increased transparency and balance were suggested. Also, the group discussed the possibility of entering threshold levels for some criteria such as working conditions. It was suggested that account should be taken only of options where working conditions were considered acceptable, and then no more discussions on working conditions would be necessary at this level.

\subsection{Sensitivity analysis}

A sensitivity analysis was performed by varying the weights with a factor of 3 , up and down. This showed that none of the changes altered the ranking of spreading on arable land as the preferred option. The two mid-alternatives, co-incineration and Bio-Con that were ranked fairly equal in the MCA, changed places on 5 of 18 possible variations of weights with a factor of 2 or 3 . 
Table 2

Spreadsheet used in the multi-criteria analysis of the four sludge handling options

\begin{tabular}{|c|c|c|c|c|c|c|c|c|c|}
\hline \multirow[t]{2}{*}{ Criterion } & \multicolumn{2}{|l|}{ Spreading } & \multicolumn{2}{|l|}{ Co-incineration } & \multicolumn{2}{|l|}{ Bio-Con } & \multicolumn{2}{|l|}{ Cambi-Krepro } & \multirow[b]{2}{*}{$\begin{array}{l}\text { Mean } \\
\text { weight }\end{array}$} \\
\hline & Data & $\begin{array}{l}\text { Mean } \\
\text { score }\end{array}$ & Data & $\begin{array}{l}\text { Mean } \\
\text { score }\end{array}$ & Data & $\begin{array}{l}\text { Mean } \\
\text { score }\end{array}$ & Data & $\begin{array}{l}\text { Mean } \\
\text { score }\end{array}$ & \\
\hline Economy & 680 SEK & 4.6 & 2440 SEK & 1.6 & 1380 SEK & 2.9 & 1790 SEK & 2.4 & 100 \\
\hline Resources & $-18 \mathrm{~kg} \mathrm{P}$ soil conditioners & 4.5 & & 1.4 & $-21 \mathrm{~kg} \mathrm{P}, 73 \mathrm{~kg} \mathrm{~S}$ & 2.9 & $-15 \mathrm{~kg} \mathrm{P}, 91 \mathrm{~kg} \mathrm{~S}$ & 2.7 & 52 \\
\hline Energy $^{\mathrm{a}}$ & $-40 \mathrm{kWh}$ el., $950 \mathrm{kWh}$ f.f. & 2.5 & $\begin{array}{l}-330 \mathrm{kWh} \text { el., } 30 \mathrm{kWh} \text { f.f., } \\
-2990 \mathrm{kWh} \text { heat }\end{array}$ & 4.4 & $\begin{array}{l}200 \mathrm{kWh} \text { el., } 20 \mathrm{kWh} \text { f.f., } \\
-1920 \mathrm{kWh} \text { heat }\end{array}$ & 3.5 & $\begin{array}{l}330 \mathrm{kWh} \text { el., } 80 \mathrm{kWh} \text { f.f., } \\
-960 \mathrm{kWh} \text { heat }\end{array}$ & 2.9 & 38 \\
\hline Emissions to air & $\begin{array}{l}50 \mathrm{~kg} \mathrm{CO}, 2020 \mathrm{~g} \mathrm{NO}_{x} \\
-520 \mathrm{~g} \mathrm{SO}_{x}\end{array}$ & 2.9 & $\begin{array}{l}-310 \mathrm{~kg} \mathrm{CO}_{2}, 960 \mathrm{~g} \mathrm{NO}_{x}, \\
-350 \mathrm{~g} \mathrm{SO}_{x}, 0.1 \mathrm{~g} \mathrm{Hg}, \\
\text { Dioxins? }\end{array}$ & 3.9 & $\begin{array}{l}-340 \mathrm{~kg} \mathrm{CO}_{2}, 1080 \mathrm{~g} \mathrm{NO}_{x} \\
-310 \mathrm{~g} \mathrm{SO}_{x}, 0.5 \mathrm{~g} \mathrm{Hg}, 1 \mathrm{mg} \\
\text { dioxins }\end{array}$ & 3.4 & $\begin{array}{l}-150 \mathrm{~kg} \mathrm{CO}, 640 \mathrm{~g} \mathrm{NO}_{x}, \\
-210 \mathrm{~g} \mathrm{\textrm {SO } _ { x }}, 0.1 \mathrm{~g} \mathrm{Hg} \\
\text { Dioxins? }\end{array}$ & 3.4 & 40 \\
\hline $\begin{array}{c}\text { Emissions to } \\
\text { ground }\end{array}$ & $\begin{array}{l}\text { Heavy metals and organic } \\
\text { compounds to arable land }\end{array}$ & 1.9 & Heavy metals to landfill & 3.2 & $\begin{array}{l}\text { Heavy metals to landfill and } \\
\text { to disposal }\end{array}$ & 3.5 & $\begin{array}{l}\text { Heavy metals to landfill and } \\
\text { to disposal }\end{array}$ & 4.0 & 66 \\
\hline Acceptance & $\begin{array}{l}\text { Precautionary principle, } \\
\text { disgust }\end{array}$ & 2.5 & Disgust & 2.9 & Location problem & 3.4 & Location problem & 3.4 & 43 \\
\hline Reliability & High, but seasonal & 4.4 & High & 4.4 & Uncertain & 2.0 & Uncertain & 1.9 & 67 \\
\hline $\begin{array}{l}\text { Working envi- } \\
\text { ronment }\end{array}$ & & 4.1 & Disgust & 3.4 & Chemicals, dust & 2.1 & $\begin{array}{l}\text { Chemicals, high pressure } \\
\text { and temperature }\end{array}$ & 1.9 & 57 \\
\hline Hygiene & Some risk & 3.6 & No risk & 4.0 & No risk & 4.1 & No risk & 4.1 & 25 \\
\hline Sum & & 31 & & 29 & & 28 & & 27 & \\
\hline Weighted sum & & 1760 & & 1480 & & 1440 & & 1370 & \\
\hline
\end{tabular}

Criteria and data that had been pre-entered are shown in regular font, while comments and other quantities added during the meeting are italicised. All data refer to one metric tonne of dry matter sewage sludge. Environmental data is reported according to common LCA practice, i.e. positive values refer to consumption of resources and emissions of pollutants; negative values refer to avoided burdens, i.e. saved resource consumption and avoided emissions.

a el. refers to electricity and f.f. to fossil fuels. 


\section{Construction of SDIs}

After the MCA came the task of formulating SDIs and, when possible, targets for sustainable development. A first step in this procedure, however, had been taken already before the MCA, when selecting the criteria to include in that exercise. In the continued process the administration of scores in the MCA, as well as the important arguments brought forward in the discussion during that meeting, were used as a basis for SDI construction in combination with already existing indicators at SWC (Eriksson, 2000; Frank et al., 2001) and SDIs suggested elsewhere (Azar et al., 1996; Holmberg, 1995; Lundin, 1999; Lundin et al., 1999; Nilsson and Bergström, 1995; NVV, 1999a). This work was carried out by the researchers alone and then fed back to the working group (see Fig. 2).

The SDIs were selected and constructed against a background of the following prerequisites agreed upon by the SWC participants:

- When discussing sustainable development, the time perspective ranges from 50 years and beyond, while the geographic perspective includes, also at the level of a specific organisation, local as well as global aspects.

- Phosphorus is regarded as a resource that should be recycled within the country as far as possible, leaving what remains of the global high-quality reserves of phosphorus to parts of the world in greater need of agricultural soil enrichment.

- When recovering phosphorus from sewage, whatever be the method used, the quality of the resulting product is a matter of decisive importance.

- Sustainable solutions in general terms require common acceptance but, due to the time perspective, poor acceptance at present does not necessarily have to be regarded as a permanent hindrance to a solution that is otherwise assessed to be sustainable.

- The use of fossil fuels is not considered to be consistent with sustainable development.

- Handling of digested sludge has not been known, as yet, to spread any disease in Sweden (NVV, 1999b) a situation that is confirmed by international research (e.g. Gerba et al., 2002). With the pasteurisation step assumed in this study, the hygiene risk was regarded as very small.

On this basis, two sets of preliminary SDIs and targets were constructed, including one subset applied to sludge handling and one subset extended to apply to the whole wastewater system (system boundaries in Fig. 3, sets 1 and 2, respectively) where this was considered possible. These preliminary sets of SDIs and targets were evaluated and revised over two subsequent meetings with SWC before the final SDIs were approved.

The resulting SDIs and related targets are listed in Table 3. The two criteria of emissions to air and hygiene that were included in the MCA were excluded at this stage because of the overlap with energy and the low hygiene risk related to sludge handling, respectively.

The set of SDIs and targets presented in Table 3 is not to be regarded as a final set in any aspect other than representing the final result of this case study. To be useful this set will need to be continuously revised. The future will show to what extent that will take place, and whether the SDIs are useful in the work within SWC towards increased sustainability. 
Table 3

SDIs developed for Stockholm Water Company

\begin{tabular}{|c|c|c|c|c|c|}
\hline Criterion & SDI & Explanation & Unit & System level & Target \\
\hline Economy & Cost & Total cost for SH/WWS & SEK (pe. y) $)^{-1}$ & SH/WWS & As low as possible \\
\hline \multirow[t]{2}{*}{ Resources } & Recycling of $\mathrm{P}$ & $\begin{array}{l}P \text { that is recycled and thereby forms a } \\
\text { potential substitute for artificial fertil- } \\
\text { izers }\end{array}$ & $\%$ of wastewater $\mathrm{P}$ & $\mathrm{SH}$ & $100 \%$ \\
\hline & $\begin{array}{l}\text { Recycling of } \mathrm{P} \\
\text { and } \mathrm{N}\end{array}$ & $\begin{array}{l}\mathrm{P} \text { and } \mathrm{N} \text { that is recycled and thereby } \\
\text { forms a potential substitute for artificial } \\
\text { fertilizers }\end{array}$ & $\%$ of wastewater $\mathrm{P}$ and $\mathrm{N}$ & WWS & $100 \%$ \\
\hline \multirow[t]{3}{*}{ Energy } & Quantity & $\begin{array}{l}\text { Heat, fuels and electricity, or energy }{ }^{a} \text {, } \\
\text { used }\end{array}$ & $\mathrm{KWh}(\text { pe } \mathrm{y})^{-1}$ & SH/WWS & As low as possible \\
\hline & & $\begin{array}{l}\text { Heat, fuels and electricity, or energy }{ }^{\mathrm{a}} \text {, } \\
\text { recovered }\end{array}$ & $\mathrm{KWh}(\text { pe } \mathrm{y})^{-1}$ & SH/WWS & As high as possible \\
\hline & Quality & $\begin{array}{l}\text { Use of fuels and electricity from renew- } \\
\text { able sources }\end{array}$ & $\begin{array}{l}\% \text { of total use of fuels and elec- } \\
\text { tricity }\end{array}$ & SH/WWS & $\begin{array}{l}\text { Only energy from renewable sources should be } \\
\text { used }\end{array}$ \\
\hline \multirow[t]{2}{*}{ Emissions to ground } & Product quality & $\begin{array}{l}\text { Heavy metals and organic contami- } \\
\text { nants in product }{ }^{\mathrm{b}}\end{array}$ & $\mathrm{mg}(\mathrm{kg} \mathrm{P})^{-1}$ & SH & Short-term target ${ }^{\mathrm{c}}$, long-term target ${ }^{\mathrm{d}}$ \\
\hline & User behaviour & Aware and responsible users & $\%$ of users & WWS & $80 \%$ \\
\hline Acceptance & Acceptance & $\begin{array}{l}\text { General acceptance of use of } P \text { products } \\
\text { produced from sewage }\end{array}$ & $\begin{array}{l}\% \text { of population, farmers and } \\
\text { food producers, respectively }\end{array}$ & SH & $\begin{array}{l}\text { General acceptance for use on agricultural land of } \\
\text { certified P products produced from sewage }\end{array}$ \\
\hline Reliability & Reliability & Accessibility per site and year & $\%$ & SH & $95 \%$ \\
\hline \multirow[t]{3}{*}{ Working conditions } & Satisfaction & $\begin{array}{l}\text { Employees that are satisfied with their } \\
\text { working situation }\end{array}$ & $\begin{array}{l}\% \text { of employees involved in the } \\
\text { SH/WWS chain }\end{array}$ & SH/WWS & $\begin{array}{l}\text { All employees involved in the SH/WWS chain } \\
\text { should be satisfied with their working situation }\end{array}$ \\
\hline & Stress & $\begin{array}{l}\text { Employees that feel adequately } \\
\text { stressed }\end{array}$ & $\begin{array}{l}\text { \% of employees involved in the } \\
\text { SH/WWS chain }\end{array}$ & SH/WWS & $\begin{array}{l}\text { All employees involved in the SH/WWS chain } \\
\text { should feel adequately stressed }\end{array}$ \\
\hline & Influence & $\begin{array}{l}\text { Employees that feel that they can influ- } \\
\text { ence their working situation }\end{array}$ & $\begin{array}{l}\% \text { of employees involved in the } \\
\text { SH/WWS chain }\end{array}$ & SH/WWS & $\begin{array}{l}\text { All employees involved in the SH/WWS chain } \\
\text { should feel that they can influence their working } \\
\text { situation }\end{array}$ \\
\hline
\end{tabular}

System level refers to the system boundaries in Fig. 3; SH: sludge handling (system boundaries set 1) and WWS: entire wastewater system (system boundaries set 2).

${ }^{\text {a }}$ Used to aggregate energies of different quality (Hellström and Kärrman, 1997).

Compounds mentioned in this context were the following heavy metals: $\mathrm{Ag}, \mathrm{Au}, \mathrm{Cd}, \mathrm{Cr}, \mathrm{Cu}, \mathrm{Hg}, \mathrm{Ni}, \mathrm{Pb}$ and $\mathrm{Zn}$, and the following organic compounds: brominated flame retardants, linear alkyl benzene sulphonates, nonylphenol, PAHs and PCBs.

c Agricultural land must not be exposed to higher levels of contaminants than what is regarded as safe for living organisms on scientific basis.

${ }^{\mathrm{d}}$ No more metals must be added to agricultural land than what is removed with the crop. 


\section{Discussion}

\subsection{SDIs for different applications}

Within companies, SDIs can be used for a variety of applications such as reporting, planning, control, benchmarking, formulation of targets and as support for decision-making. One of the difficulties encountered in this case study was that of defining the objectives of the SDI program in terms of its applications. SWC wanted the case study to support the choice of technology for sludge handling and, at the same time, to be relevant for the development of SDIs for management by objectives of the entire wastewater system. Hence, the case study had to cover the assessment of a specific choice of technology relating to one specific sub-system, as well as SDIs for management by objectives of the entire wastewater system. The technology choice, and its whole assessment, requires a prospective view. The use of SDIs for management by objectives and reporting on that (internally and externally) instead requires an accounting, retrospective view. To manage this dual objective (SDIs as support for choice of technology as well as for management by objectives), the procedure shown in Fig. 2 was developed, where the SDIs for management by objectives of the wastewater system are approached through the evaluation of technical solutions and the construction of SDIs at the system level of sludge handling. A positive effect of this approach was that the problem became more apprehensible thanks to the limited scope and the concrete issue of sludge handling in focus of all discussions. Sludge handling being a major concern of SWC may also have contributed to the commitment shown by its representatives throughout the study.

\subsubsection{SDIs as support for choice of technology}

It is not unusual to use the results from LCA and other assessments in combination with MCA as an input to the procedure of technology choice, as done in this case study. Similar approaches to decision making in a technical context are reviewed by e.g. Azapagic (1999) and Baumann and Tillman (2004). Once criteria have been selected (as is necessary to perform an MCA) an important step towards the construction of indicators is already taken, indicators being closely related to criteria.

In this specific case, the SDIs constructed in the process of choosing technology option are likely to work as support in similar decision-making situations at SWC. For this application the indicators do not need to be related to targets of sustainable development.

\subsubsection{SDIs for management by objectives}

For the application of SDIs to management by objectives, the setting of quantitative targets of sustainable development is an important aspect. This proved to be a difficult task in the study. For several of the SDIs only directions could be formulated, e.g. as low as possible for total cost and energy use, and as high as possible for energy recovery (see Table 3). For recycling of nutrients the target was set to $100 \%$. Such a target is impossible to reach, as there will always be certain losses from the system. Sustainable development, however, is a question of moving in the right direction. What a sustainable society, the ultimate goal, would look like is a closely connected but different matter. Therefore, setting 
targets that are hard, or even impossible to reach, need not be a drawback as long as these targets lead the organisation in the required direction. Less ambitious short-term targets, on the way towards the long-term targets, will however, make it easier to discern and communicate progress made.

\subsection{A systems approach to SDIs}

This case study had as point of departure, a procedure including the use of LCA (Fig. 1). Among the advantages of LCA is that it is systemic, taking into consideration the life cycle of a product or process from cradle to grave. The LCA model of the technical system is a description of energy and material flows, and their links to potential environmental impacts, on both global and regional levels. LCA therefore provides a robust base for the construction of resource and environment related SDIs.

LCA is also systematic. The method of model construction, data gathering and processing can be made clear, transparent and standardised. The various potential environmental effect categories, as well as specific assumptions and simplifications, can be made explicit, facilitating rational debate and decision making.

Other aspects of sustainability also need to be included in a comprehensive set of SDIs. In this study it was possible to apply a life cycle perspective also to the economic assessment. In other cases, where the municipal perspective on economy is not relevant, but the economic interests of several stakeholders have to be taken into consideration, the application of a life cycle perspective may be more complicated.

Social aspects are not as easily quantified and are therefore hard to handle systematically in correspondence to environmental data in an LCA. The systemic qualities of a life cycle perspective can, however, be applied also to social aspects. In this case, for example, working conditions was considered not only for employees at SWC, but also for everyone in the sludge handling and wastewater treatment chains (Table 3, bottom right).

\subsubsection{What to include in the system under study}

A challenge when constructing SDIs for corporate use is to link the various long-term and global aspects of sustainable development to the decision domain of the company, retaining both global relevance and local relevance for the company and its application of SDIs. The questions of how to indicate sustainability and what to include are important. The question of what to include relates to system boundaries on the one hand, and to what aspects to consider on the other hand. System boundaries will need to be adapted to the indicator users so that the SDIs constructed in the end carries information that is relevant to the company and its various applications of SDIs, without losing the necessary links to the long-term and global issues that are at the core of the sustainable development concept. This means balancing wide system boundaries, comprehensiveness and effectiveness ("doing the right things") against narrow system boundaries, feasibility and efficiency ("doing things right"). Correspondingly, the coverage of the set of SDIs with regard to the diverse environmental, social and economic (and other) aspects of sustainability needs to be adapted to the information need of the company and its stakeholders, without losing the links to the long-term and global issues. 


\subsubsection{Case-specific observations on system boundaries}

In this particular case, the dual objective of the study influenced the choice of system boundaries. These were set rather narrowly since the construction of SDIs was approached through focusing on different technology options for sludge handling (Fig. 3, system boundaries set 1). No new SDIs were constructed for the larger system, the wastewater system, besides the ones that could be derived from the SDIs relating to sludge handling. As a consequence, the SDIs developed within the project (Table 3) cover sludge handling well, but only parts of the wastewater system. Based on the empirical results of the study, the coverage of the SDIs suggested at sludge handling level could be extended to the wastewater system level for all criteria except those of acceptance and reliability (rows 10 and 11 in Table 3). There was also at least one important aspect of the wastewater system that was missed through the focus on sludge handling. LCA studies performed on wastewater systems generally show that energy use and emissions of nutrients and heavy metals are the parameters that are related to the greatest environmental impacts (for review see Lundin, 2003). In this case, however, emissions of nutrients to receiving waters are not covered by the SDIs suggested at the wastewater system level, as the system boundaries of the sludge handling assessments did not include receiving waters. This demonstrates the importance of working within adequately chosen system boundaries.

In order to select SDIs for use at a higher system level to follow the development of the wastewater system over time, it would have been more effective to work with wider system boundaries to provide a more complete view of the system, including the urban water system and also surrounding systems that interact with the wastewater system, such as energy, solid waste handling, fertiliser production and agriculture (Lundin and Morrison, 2002). The increased coverage, however, would have to be balanced against the loss of detail when widening the system boundaries.

\subsection{Evaluation of the project}

Construction of SDIs calls for involvement of the indicator users in order to gain commitment, motivation and relevance (Schelin et al., 2003). In the case study with SWC much appreciation was expressed over the co-operative approach used, as it enabled both researchers and practitioners to contribute important knowledge and experience.

In this case "indicator users" only included SWC, as the SDIs were intended mainly for internal applications: as support for internal decision making and for management by objectives. Both applications, however, require the recognition of the interests of external stakeholders. External stakeholders could have been included in the study, but in this case, dealing with an issue well known to SWC, also as regards the views held by external stakeholders, we feared that such a broadening of the project would delay and complicate the project rather than contribute to it. On other occasions it may well be better to include external stakeholders in the process.

Many of the difficulties experienced in this study relate back to the initial phase. In retrospect, considerably more time and effort should have gone to the problem definition, i.e. to define the SWC interpretation of sustainable development, the information need within the organisation and, in that context, the purpose of the SDIs. It is being increasingly recognised that an examination of who needs what information for what purpose, will help 
in constructing relevant SDIs (Burström Von Malmborg and Lindqvist, 2002; Rikhardsson, 1998; Seager, 2001).

To first collect information, by use of a life cycle perspective on the environmental, economic and social aspects of sustainable development, and then construct SDIs on the basis of that information (Fig. 2), was a major alteration of the procedure for indicator construction taken as point of departure in the case study (Fig. 1). This mode of action was chosen in order to diminish the risk of overlooking important facts. We are well aware that such data collection is costly and time consuming, and it may be unrealistic as a recommendation for many companies. Nevertheless, we do believe that the application of a life cycle perspective carries a long way, even without the performance of quantitative assessments.

\section{Concluding remarks}

This study shows to the importance of considering the intended SDI uses, including application, system level and users, in the construction of SDIs, in order to balance effectiveness and efficiency with regard to the project as well as to the resulting SDIs. Such consideration, in turn, requires an honest examination of the preconditions of each company in terms of its views on sustainable development as well as of its external pressures, resources and requirements in terms of sustainable development information.

\section{Acknowledgements}

Financial support from The Swedish Research Council for Environment, Agricultural Sciences and Spatial Planning (Formas) is gratefully acknowledged. We also want to thank the staff at Stockholm Water Company for their committed and creative input to the project.

\section{References}

Azapagic A. Life cycle assessment and its application to process selection, design and optimisation. Chem Eng J 1999;73:1-21.

Azar C, Holmberg J, Lindgren K. Socio-ecological indicators for sustainability. Ecol Econ 1996;18(2):89-112.

Azzone G, Noci G, Manzini R, Welford R, Young WC. Defining environmental performance indicators: an integrated framework. Business Strat Environ 1996;5(2):69-80.

Balkema AJ, Preisig HA, Otterpohl R, Lambert FJD. Indicators for the sustainability assessment of wastewater treatment systems. Urban Water 2002;4(2):153-61.

Balmér P, Book K, Hultman B, Jönsson H, Kärrman E, Levlin E, Palm O, Schönning C, Seger A, Stark K, Söderberg H, Tideström H, Åberg H. System för återanvändning av fosfor ur avlopp. Stockholm, Sewden: Naturvårdsverket (Swedish Environmental Protection Agency) Report 5221; 2002 (in Swedish).

Baumann H, Rydberg T. Life cycle assessment: a comparison of three methods for impact analysis and evaluation. J Cleaner Prod 1994;2(1):13-20.

Baumann H, Tillman A-M. The hitchhikers guide to LCA - An orientation to life cycle assessment methodology and application. Lund, Sweden: Studentlitteratur; 2004.

Bennett M, James P. Sustainable measures - Evaluation and reporting of environmental and social performance. Sheffield, UK: Greenleaf; 1999. 
Burström Von Malmborg F, Lindqvist A. Environmental information management in municipalities. Local Environ 2002;7(2):189-201.

Enskog Broman L. Kadmium - miljö- och hälsoaspekter vid slamspridning. Stockholm, Stockholm Vatten: Rapport nr 2,2000.

Eriksson A. Resultatmål för 2001-2004 (Performance objectives for 2001-2004), Daniel Hellström, Stockholm Vatten, 2000 (in Swedish).

Fiksel J, McDaniel J, Mendenhall C. Measuring progress towards sustainability; principles, process, and best practices. In: Proceedings of the Greening of Industry Network Conference; 1999.

Foxon TJ, McIlkenny G, Gilmour D, Oltean-Dumbrava C, Souter N, Ashley R, et al. Sustainability criteria for decision support in the UK water industry. J Environ Plan Manage 2002;45(2):285-301.

Frank I, Henriksson B, Olsson K, Reinius L-G, Sjöberg G-M, Värnhed B. Stockholm Vatten AB Nyckeltal 1991-2000 (Stockholm Water Company Indicators 1991-2000). Stockholm: Stockholm Vatten; 2001 (in Swedish).

Gerba CP, Pepper IL, Whitehead LF. A risk assessment of emerging pathogens of concern in the land application of biosolids. Wat Sci Technol 2002;46(10):225-30.

Holmberg J. Socio-ecological principles and indicators for sustainability. Institute of Physical Resource Theory, Göteborg, Chalmers University of Technology, 1995.

Hultman B, Levlin E, Lambert AJ. Effects of wastewater treatment technology on phosphorus recovery from sludges and ashes. In: Proceedings of the Second International Conference on Recovery of Phosphates from Sewage and Animal Wastes; 2001.

ISO 14042. Environmental management - Life cycle assessment, life cycle impact assessment International Organization for Standardization Geneva, Switzerland, 2000.

Kärrman E, Jönsson H. Normalising impacts in an environmental system analysis of wastewater systems. Wat Sci Technol 2001;43(5):293-300.

Lundin M. Assessment of the environmental sustainability of urban water systems. Technical Environmental Planning. Göteborg: Chalmers University of Technology, 1999.

Lundin M. Indicators for measuring the sustainability of urban water systems - a life cycle approach. Department of Environmental Systems Analysis. Göteborg, Sweden: Chalmers University of Technology, 2003.

Lundin M, Morrison GM. A life cycle assessment based procedure for development of environmental sustainability indicators for urban water systems. Urban Water 2002;4(2):145-52.

Lundin M, Molander S, Morrison GM. A set of indicators for the assessment of temporal variations in the sustainability of sanitary systems. Wat Sci Technol 1999;39(5):235-42.

Lundin M, Olofsson M, Pettersson GJ, Zetterlund H. Environmental and economic assessment of sewage sludge handling options. Resour Conserv Recycl 2004;41(4):255-78.

Nilsson J, Bergström S. Indicators for the assessment of ecological and economic consequences of municipal policies for resource use. Ecol Econ 1995;14:175-84.

Noci G. Environmental reporting in Italy: Current practice and future developments. Business Strat Environ 2000;9(4):211-23.

NVV. Miljömålen i Sverige. System med indikatorer för nationell uppföljning av miljökvalitetsmålen. Rapport 5006. Stockholm, Naturvårdsverket, 1999a.

NVV. Smittrisker och slam i jordbruket (Sludge and risk of infection in agriculture). Swedish Environmental Protection Agency, 1999b (in Swedish). http://www.naturvardsverket.se/.

NVV. Metaller och organiska ämnen i avloppsslam (Metals and organic substances in sewage sludge). Swedish Environmental Protection Agency (in Swedish). http://www.naturvardsverket.se/.

NVV, LRF, VAV. Användning av avloppsslam i jordbruket. Stockholm, Sweden: Naturvårdsverket (Swedish Environmental Protection Agency). Report 4418, 1995 (in Swedish).

OECD. Towards sustainable development - Environmental indicators. Paris: Organisation for Economic Cooperation and Development; 1998.

Olsthoorn X, Tyteca D, Wehrmeyer W, Wagner M. Environmental indicators for business: a review of the literature and standardisation methods. J Cleaner Prod 2000;9(5):453-63.

Pettersson G. Livscykelanalys av fyra slamhanteringsmetoder. Göteborg: Chalmers tekniska högskola, Institutionen för Miljösystemanalys, 2001.

Rikhardsson PM. Information systems for corporate environmental management accounting and performance measurement. Greener Manage Int 1998;21:51-69. 
Schaltegger S, Burritt R. Contemporary environmental accounting. Sheffield, UK: Greenleaf Publishing; 2000.

Schelin J, von Malmborg F, Carlsson J-E. Towards integrated environmental management: The case study of a Swedish urban engineering company. Int J Corporate Sustain 2003;10(2):41-50.

Seager J. Perspectives and limitations of indicators in water management. Regional Environ Change 2001;2:85-92.

Smil V. Phosphorus in the environment: Natural flows and human interferences. Ann Rev Energy Environ 2000;2000(25):53-88.

Spinosa L, Veslind PA. Sludge into biosolids: processing, disposal, utilization. IWA Publisher; 2001.

Steen B. A systematic approach to environmental priority strategies in product development (EPS), Version 2000 - Models and data of the default method. CPM Report 1999:5, Göteborg, Sweden, 1999.

Steen I. Phosphorus availability in the 21st century. Management of a non-renewable resource. Phosphorus and Potassium 1998;217:25-31.

Stirling A, Mayer S. Rethinking risk - a pilot multi-criteria mapping of a genetically modified crop in agricultural systems in the UK. Brighton, UK: Science and Technology Policy Research, University of Sussex; 1999.

SWC. Environmental and Annual Report 2001. Stockholm, Sweden: The Stockholm Water Company, 2002.

UNCSD. Indicators of sustainable development framework and methodologies. New York: United Nations; 1996.

van Leeuwen CJ. General introduction. In: van Leeuwen CJ, Hermens JLM, editors. Risk assessement of chemicals: An introduction. The Netherlands: Kluwer Academic Publishers; 1995.

Veleva V, Ellenbecker M. Indicators of sustainable production: framework and methodology. J Cleaner Prod 2001;9(6):519-49.

Veleva V, Baily J, Jurczyk N. Using sustainable production indicators to measure progress in ISO 14001, EHS System and EPA Achievement Track. Corporate Environ Strat 2001;8(4):326-38.

Verbruggen H, Kuik O. Indicators of sustainable development: An overview. In: Kuik O, Verbruggen H, Search of indicators of sustainable development. Dordrecht, The Netherlands: Kluwer Academic Publishers, 1991. p. $1-6$.

Zetterlund H. Utvärdering av olika alternativ för att ta hand om rötat slam från avloppsreningsverk - En ekonomisk och teknisk systemstudie i Göteborg. Göteborg, Institutionen för energiteknik, Chalmers tekniska högskola, 2001. 